\title{
Evaluation of resistance to Dermo in eastern oyster strains tested in Chesapeake Bay
}

\author{
Bonnie L Brown', Arthur J Butt ${ }^{2}$, Donald Meritt ${ }^{3}$ \& Kennedy T Paynter ${ }^{4,5}$ \\ ${ }^{1}$ Department of Biology and Center for Environmental Studies, Virginia Commonwealth University, Richmond, VA, USA \\ ${ }^{2}$ EcoGen, Richmond,VA, USA \\ ${ }^{3}$ Horn Point Laboratory, University of Maryland Center for Environmental Science, Cambridge, MD, USA \\ ${ }^{4}$ Chesapeake Biological Laboratory, University of Maryland Center for Environmental Science, Solomons, MD, USA \\ ${ }^{5}$ Department of Biology, University of Maryland, College Park, MD, USA
}

Correspondence: B L Brown, VCU Ecological Genetics Lab, PO Box 842012, Richmond, VA 23284-2012, USA. E-mail: blbrown@vcu.edu

\begin{abstract}
We investigated growth, Dermo disease, and survival for nine groups of oysters, Crassostrea virginica (Gmelin) cultivated in Chesapeake Bay (CB). Five regional strains (upper CB, North Carolina (NC), South Carolina (SC), Louisiana (LA) and LA triploids) and four additional hybrid strains (CB oysters mated with NC, SC, LA and Texas (TX) oysters) were held in floating rafts at three locations representative of lower CB: 'low' salinity (3-14 $\left.\mathrm{g} \mathrm{L}^{-1}\right)$, 'moderate' salinity $\left(5-20 \mathrm{~g} \mathrm{~L}^{-1}\right)$ and 'high' salinity $\left(14-24 \mathrm{~g} \mathrm{~L}^{-1}\right)$. At each site, patterns of growth and incidence of infection with Perkinsus marinus (Levine), the causative agent of Dermo disease, were similar. However, mortality trends were markedly different at each site; the CB strain being notable for accelerated mortality following infection with $P$. marinus. In addition, hybrids between $\mathrm{CB}$ and all four of the regional strains exhibited similar accelerated mortality in response to infection. Mortality was strongly correlated with infection only at the high salinity site implicating interaction of differences in both oyster strain and virulence of Dermo between moderate and high salinity areas as factors in differential mortality across sites.
\end{abstract}

Keywords: growth, dermo disease, survival, Crassostrea virginica (Gmelin), Chesapeake Bay

\section{Introduction}

Oyster aquaculture is one of several strategies and management approaches currently being pursued in Chesapeake Bay $(\mathrm{CB})$ with the intent of enhancing numbers of this once abundant CB species (USEPA 2000). Continued expansion of the range of the oyster parasites Haplosporidium nelsoni (Haskin, Stauber and Mackin) and Perkinsus marinus (Levine), causative agents of MSX and Dermo diseases, respectively, is responsible for significant mortalities within the first 2 years of an oyster's life, and is one of the major impediments to oyster aquaculture in the region (Burreson \& Calvo 1996). In CB, several studies have shown that although most rapid oyster growth occurs at higher salinities, parasite-induced oyster mortality also is positively correlated with higher salinities (Dame 1976; Paynter, Pierce \& Burreson 1995). Brown, Butt and Paynter (1995) compared growth and survival of native North Carolina (NC) oysters to a domestic strain of $\mathrm{CB}$ oyster selectively bred for rapid growth. After 12 months, Dermo infection exceeded $80 \%$ (infection intensity greater than 0.5) in both strains held at high salinity, at which time the selectively bred Chesapeake strain exhibited reduced growth and high mortality. Meanwhile, despite high levels of infection, the native NC strain cultured at high salinity experienced $<20 \%$ mortality and continued to grow. This strain reached a harvestable size of $76 \mathrm{~mm}$ within 18 months. In contrast, at low salinity where both strains experienced low mortality $(<5 \%$ ), the selectively bred CB oyster grew faster than the native NC strain. The trends in growth and survival indicated that Dermo-resistant strains from NC might be successfully grown at all salinities without significant disease-related mortality. Subsequently, Brown, Butt, Shelton and Paynter (1998) reported similar results for oysters held at two CB sites, Mobjack Bay, Virginia and Wye River, Maryland. In that study, oysters of upper $\mathrm{CB}$ heritage perished when challenged with Dermo while NC-heritage oysters tolerated infection and continued to grow. 
Many producers of oyster spat along the western Atlantic and Gulf of Mexico coasts are small operations with little or no access to selectively bred oyster strains. Often these operations choose local native oysters for spat production and the resulting progeny are widely distributed across the lower $\mathrm{CB}$ region for gardening and commercial cultivation. Once outplanted in the Bay, non-native strains are known to survive and reproduce (Milbury, Meritt, Newell \& Gaffney 2004), possibly hybridizing with the local Chesapeake strain. Therefore, with regard to oyster cultivation in $\mathrm{CB}$, it is important to assess disease resistance in different native oyster strains reared at salinities representative of habitats in lower CB. An oyster strain that demonstrates outstanding performance at low salinity may perish at high salinity because of the effects of disease. Conversely, an oyster strain that performs well at high salinity may grow very slowly at low salinity. In fact, based on the results of prior studies, it is feasible that several strains of oyster could be required for the most effective cultivation strategy in the wide variety of lower Chesapeake habitats. Therefore, the current study was designed to examine a broader range of sites in the lower Bay, provide additional performance data for other native oyster strains, and to examine the consequences of hybridization among native oyster strains. To examine performance in terms of growth, Dermo disease resistance, and oyster survival, this study evaluated eight groups of oysters cultivated in floating trays at four typical locations. The overarching goal of this study was to examine growth and survival characteristics of various oyster stocks when cultivated in lower CB.

\section{Materials and methods}

\section{Experimental design and oyster strains}

Prior work documented that growth, mortality, and Dermo disease resistance patterns of native and selectively bred $\mathrm{CB}$ oysters and of native $\mathrm{NC}$ oysters reared in $\mathrm{CB}$ are consistent from year to year at particular sites and that a certain strain of native NC oysters exhibits significant resistance to Dermo when cultivated in the Bay (Brown et al. 1998; Brown, Butt, Meritt, Shelton \& Paynter 2005). The original experimental design was intended to compare performance of native $\mathrm{CB}$ oysters with performance of four other geographic oyster strains and hybrids between those and Chesapeake oysters. Mature adult oysters were collected from five geographically distinct
Table 1 Oyster, Crassostrea virginica (Gmelin), strains tested in lower Chesapeake Bay for growth, Dermo disease, and survival

\begin{tabular}{ll}
\hline Strain designation & Origin of broodstock \\
\hline $\mathrm{TX} \times \mathrm{CB}$ & Chesapeake Bay $\times$ Texas diploid \\
$\mathrm{SC} \times \mathrm{CB}$ & Chesapeake Bay $\times$ South Carolina diploid \\
$\mathrm{NC} \times \mathrm{CB}$ & Chesapeake Bay $\times$ North Carolina diploid \\
$\mathrm{LA} \times \mathrm{CB}$ & Chesapeake Bay $\times$ Louisiana diploid \\
$\mathrm{CB}$ & Upper Chesapeake Bay diploid \\
$3 \mathrm{~N}(\mathrm{LA})^{*}$ & Louisiana triploid \\
$\mathrm{LA} *$ & Louisiana diploid \\
$\mathrm{NC} \dagger$ & North Carolina diploid \\
$\mathrm{SC} \ddagger$ & South Carolina diploid \\
\hline
\end{tabular}

*Deployed Fall 1996.

$\dagger$ Deployed Winter 1997.

†Deployed Fall 1997.

oyster populations during the Spring of 1995 (upper CB, NC, South Carolina (SC), Louisiana (LA) and Texas (TX)), and conditioned at the Horn Point Laboratory in Cambridge, Maryland. Once the various strains arrived at the Maryland hatchery, they proved very difficult to condition both males and females to spawn simultaneously. Because this hatchery had produced progeny from the pure NC strain on several prior occasions, the difficulty with conditioning was assumed not to be a stenohaline effect (i.e., not because of inherent salinity intolerance of the pure heritage strains). As a result, males from each regional broodstock were hybridized with female native CB oysters and the hybrid offspring were introduced at each site in the Fall of 1995 alongside a pure CB line for comparison (Table 1). Additional pureheritage geographic oyster strain test groups were deployed at similar sizes as the original groups as they became available: triploid Crassostrea virginica from LA stock (3N) and diploid LA deployed in Fall 1996, NC deployed in the Winter of 1997, and SC were deployed in the Fall of 1997. Prior to each introduction, spat were tested or re-tested for Dermo to confirm pathogen-free status and they were introduced sufficiently late in the season to avoid infection during the first months of cultivation.

\section{Study sites}

Three representative sites were selected in lower CB based on accessibility and salinity (Fig. 1). The sites were characterized as 'low' (Piankatank River) where salinity averaged $7 \mathrm{~g} \mathrm{~L}^{-1}$ (ranging from 3 to $14 \mathrm{~g} \mathrm{~L}^{-1}$ ), 'moderate' (Mobjack Bay) where salinity averaged $15 \mathrm{~g} \mathrm{~L}^{-1}$ (range 5-20 $\mathrm{gL}^{-1}$ ) and 'high' 


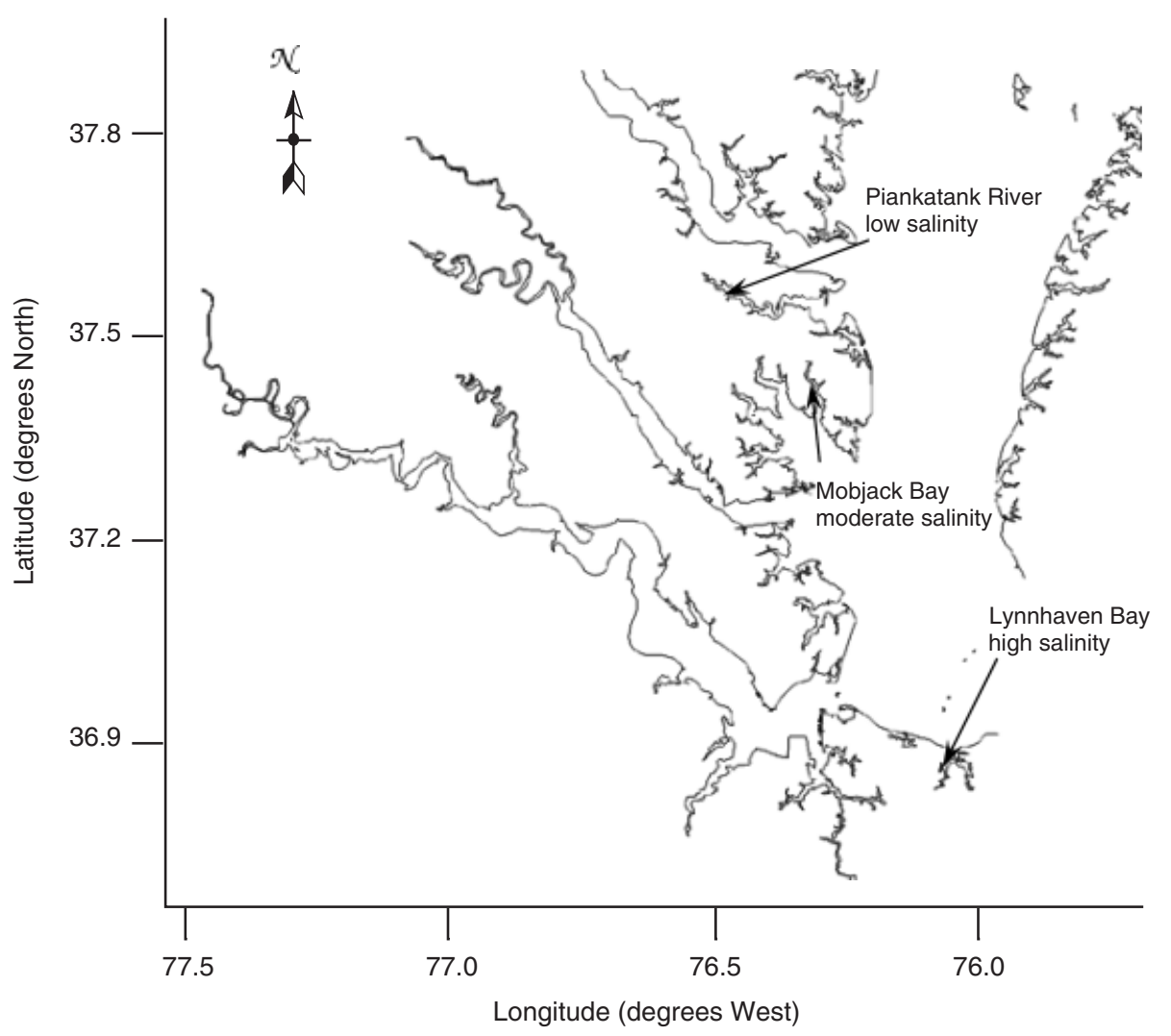

Figure 1 Chesapeake Bay locations (Virginia, United States) where experimental strains of oyster, Crassostrea virginica (Gmelin), were reared. Piankatank River: low salinity site (ca. $7 \mathrm{~g} \mathrm{~L}^{-1}$ ), Mobjack Bay: moderate salinity site (ca. $15 \mathrm{~g} \mathrm{~L}^{-1}$ ), Lynnhaven Bay: high salinity site (ca. $22 \mathrm{~g} \mathrm{~L}^{-1}$ ).

(Lynnhaven Bay) where salinity averaged $22 \mathrm{~g} \mathrm{~L}^{-1}$ (range 14-24 $\mathrm{g} \mathrm{L}^{-1}$ ). The Mobjack Bay site provided a degree of replication with other previous studies as both CB and NC oysters had been cultivated at that site in two prior studies (Brown et al. 1998, 2005). The low salinity Piankatank River site provided a method for examining the transferability of data to other Bay sites of similar salinity as the two prior studies (Brown et al. 1998, 2005) included culture characteristics of $\mathrm{CB}$ and NC oysters at a different site in CB of similarly low salinity (Wye River).

\section{Culture containers}

Floating trays were employed as culture containers to limit exposure to predators, siltation and other consequences of benthic habitation. As outlined by Paynter and Burreson (1991), each tray consisted of a wooden frame approximately $91 \mathrm{~cm} \times 61 \mathrm{~cm}$ with polyethylene mesh (19 mm diamond mesh) folded into a rectangular box that hung below the wooden frame and was secured to the frame along the edges.
The resulting mesh box was $91 \mathrm{~cm}$ long $\times 61 \mathrm{~cm}$ wide $\times 20 \mathrm{~cm}$ deep. A $91 \mathrm{~cm} \times 61 \mathrm{~cm}$ panel of CFCfree extruded styrofoam wedged underneath the wooden frame was used to keep the tray afloat. Trays were originally equipped with $6 \mathrm{~mm}$ liners and as oysters grew, the liners were removed and/or replaced with new liners of successively larger mesh. Final diagonal mesh width in the trays was $19 \mathrm{~mm}$.

Oyster strains introduced in 1996 and 1997 were held in quarantine until Dermo infection intensities were observed to be on the decline, October-January. From then on, the oyster groups were cultivated at all three sites in adjacent replicate floating trays as described by Brown et al. (1998). Approximately 3000 oyster spat of each strain (introduced at 6-10 mm) were initially placed at a site in replicate small-mesh bags inside separate floating trays. Each strain was examined monthly for evidence of crowding (i.e., oysters were laying in the tray more than one deep), at which time equal portions were transferred to similarly sized trays of successively larger mesh sizes. In this way, densities were considered to 
be non-limiting at all stages of the study. At all times, different families held at the same site were kept in separate trays.

\section{Data collection}

Beginning October 1995 and continuing through September 2001, salinity and temperature were recorded for each site, measurements were made for shell height, total mortality was quantified in each tray, and samples were collected for physiological condition and determination of prevalence and intensity of P. marinus (Dermo) infection. Each month, average shell height was estimated by collecting a haphazard grab of 25-50 oysters from each tray and measuring shell height from the hinge to the ventral shell margin to the nearest millimetre for all individuals in the grab. Mortality was estimated for each tray in a manner similar to estimation of shell height. Five of the individuals in each grab were sacrificed each month for condition assessment according to Paynter and DiMichele (1990). The level of infection with $P$. marinus was assayed during most months in samples of 25 oysters from each strain at each site using the fluid thioglycollate method of Ray (1952, 1954, 1966). Infection intensity was scored as: negative $=0$, light $=1$, moderate $=3$ and heavy $=5$. Weighted infection prevalence (WP) was then calculated for each tray as the mean of the recorded infection intensities. Tissue samples were archived in the event it became necessary to evaluate the level of infection with H. nelsoni (MSX). However, in most cases we did not examine oyster specimens for MSX as mortalities typically associated with $\mathrm{H}$. nelsoni infection were not observed (i.e., mortality of smaller oysters early in the summer). Only for the LA strain were oyster specimens tested for $\mathrm{H}$. nelsoni infection, and then only those from Piankatank River and Mobjack Bay in April 1996 using the methods described by Stokes, Siddall and Burreson (1995).

\section{Statistical analyses}

Mean shell height, mean instantaneous growth rate, cumulative mortality and the mean weighted prevalence of infection with $P$. marinus were compared where possible among strains concurrently reared and across sites by one- and two-way repeated measures analysis of variance, linear regression, Spearman's rank order correlation and other nonparametric tests as appropriate. In cases where there was significant deviation from normal distribution or where variances were not homogenous, raw data were transformed; specifically, by the addition of 0.5 to percent mortality and weighted $P$. marinus prevalence, and by taking the natural log of instantaneous mortality (calculated as mortality at time $t_{2}$ minus mortality at time $t_{1}$ ) and of growth rate (calculated as shell height at time $t_{2}$ minus shell height at time $t_{1}$ ). Trends in performance data for the $\mathrm{CB}$ and $\mathrm{NC}$ strains were compared with data collected in two prior studies of strain performance in $\mathrm{CB}$.

\section{Results}

\section{Hydrology}

Because of the flow characteristics of $\mathrm{CB}$ which retains fresh water, salinities were less variable than those encountered in other nearby estuaries such as Pamlico Sound, NC. Salinities in Piankatank River ranged from 3 to $14 \mathrm{~g} \mathrm{~L}^{-1}$, in moderate salinity Mobjack Bay they ranged from 5 to $20 \mathrm{~g} \mathrm{~L}^{-1}$, and in the high salinity Lynnhaven Bay, salinities were recorded in the range of $14-24 \mathrm{~g} \mathrm{~L}^{-1}$ (Fig. 2). Temperatures were similar on each sampling date across all sites ranging from $-2{ }^{\circ} \mathrm{C}$ to $29^{\circ} \mathrm{C}$ during the study period. A number of severe storm events and hurricanes occurred during the study. During one episode in January 1998, all but one strain held at the low salinity site were entirely lost (CB, all hybrid strains and $3 \mathrm{~N}$ ).

\section{Mortality, disease and growth}

Mortality, disease and growth patterns observed for the native $\mathrm{CB}$ and $\mathrm{NC}$ oyster strains were similar to

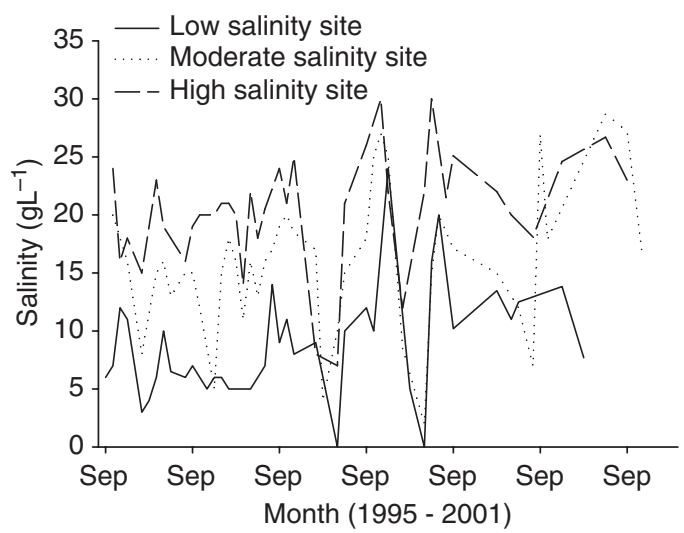

Figure 2 Salinity at three lower Chesapeake Bay sites where oysters were held during 1995-2001. 
those of previous studies (Brown et al. 1998, 2005). Significant differences existed among the growth and survival patterns of the oyster cohorts raised at the various sites in lower CB. Except for the LA strain, initial post-introduction (i.e., non-disease related) mortality at all sites and for all strains was $<1 \%$. Subsequent mortality because of predators, fouling, weather related events, etc., averaged $<1 \%$ per month prior to infection. At the low and moderate salinity sites, the LA strain grew poorly during the first 4 months of culture, then experienced rapid mortality during the early summer months. Laboratory tests to assess the presence of the H. nelsoni parasite were negative, discounting MSX as the cause of the observed mortality.

During the first and second year of culture, those strains introduced concurrently at any particular site acquired $P$. marinus infections at approximately the same time of year and at similar intensities (Fig. 3). However, there were subsequent differences in the effect of P. marinus infection among oyster strains held at the various sites. Based on linear regression of transformed data, there were no clear relationships at any site between mortality and intensity of $P$. marinus infection of the SC, 3N or LA strains. At high salinity, infection (WP) was positively correlated with mortality for the other six strains ( $P \leq 0.03$, Table 2 ). Another difference in the dynamics of P. marinus infection was that while WP reached the highest levels at the moderate salinity site $\left(\mathrm{WP}_{\max }=5.0\right)$, oyster mortality at that site was lower than at the high salinity site where mortality, especially for the hybrid oyster strains, reached $100 \%$ following the first Dermo disease challenge ( $\left(\mathrm{PP}_{\max }=3.2\right.$, Table 2 and Fig. 4).

Although it survived and grew well at the low salinity site, the native $\mathrm{CB}$ strain did not survive well at the moderate and high salinity sites. Like the $\mathrm{CB}$ strain, significant oyster mortality for the hybrid oyster strains was attributed to infection with $P$. marinus. Conversely, non-Chesapeake oyster strains demonstrated better survival despite attaining higher levels of WP. At all sites, the native $\mathrm{NC}$ and SC strains survived and grew a number of years ( 3 and 1.5 years respectively) past the time when population mean size of $76 \mathrm{~mm}$ was reached.

Significant differences were observed among growth patterns of oyster strains held at all sites (Fig. 5). At the low and moderate salinity sites, the $\mathrm{NC}$ strain was the first population to reach mean harvest size of $76 \mathrm{~mm}$ ( 23 and 25 months respectively). At the high salinity site, the $3 \mathrm{~N}$ and SC strains each reached mean harvest size at 18 months and the NC
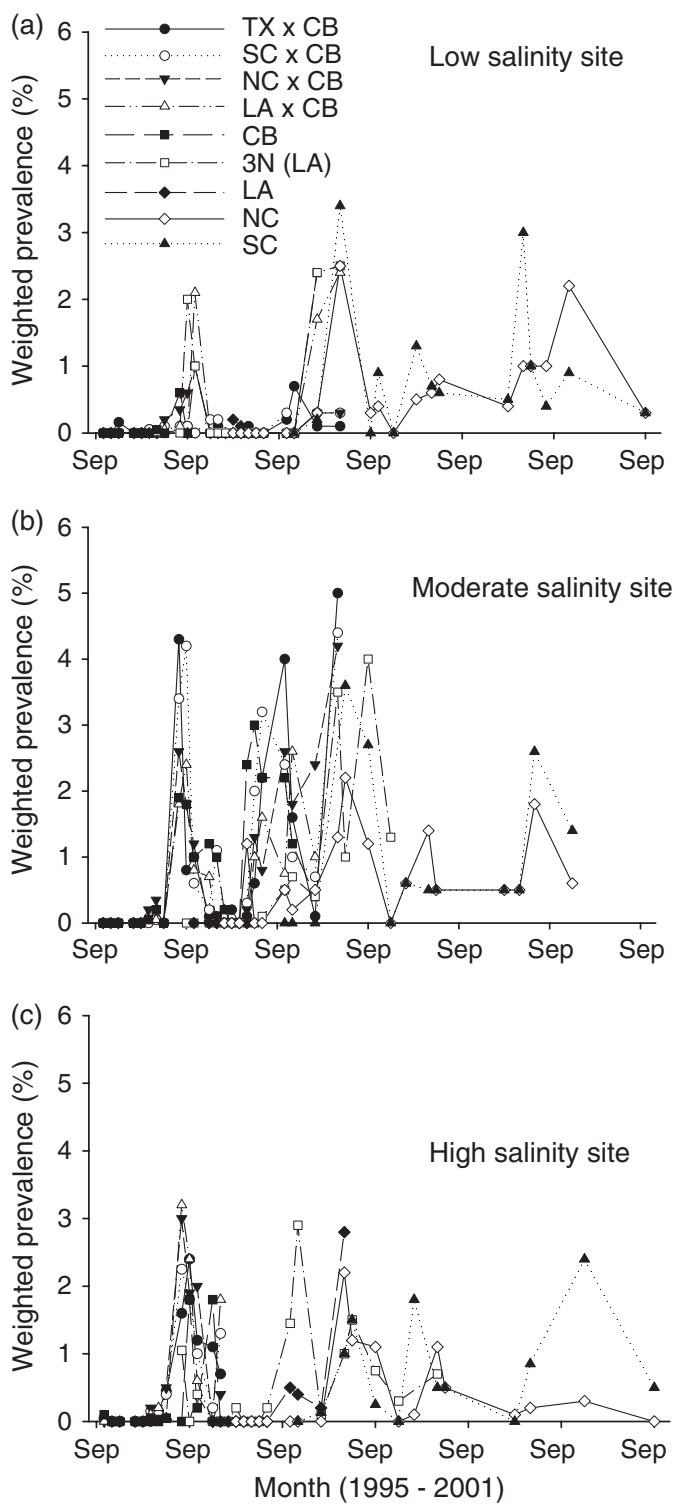

Figure 3 Weighted prevalence of Perkinsus marinus (Levine) infection in nine oyster, Crassostrea virginica (Gmelin), strains cultivated in lower Chesapeake Bay during the period 1995-2001. (a-c) Illustrates the low, moderate and high salinity sites, respectively, as defined in Fig. 1.

population reached mean harvestable size in 22 months at that site. A notable difference in growth trends was that oysters held at the low and moderate salinity sites exhibited relatively linear growth responses while their siblings held at the higher salinity site exhibited 'stepwise' growth curves similar to those previously reported (Paynter \& Burreson 1991). This phenomenon was especially pronounced for the hybrid oysters cultivated at high salinity, where 
Table 2 Total cultivation period and months to harvest size; means for final shell height, maximum observed growth rate and weighted prevalence (WP) of Perkinsus marinus (Levine) prior to onset of mortality; cumulative \% mortality; and correlation coefficients (and associated $P$-values) for level of $P$. marinus infection vs. mortality

\begin{tabular}{|c|c|c|c|}
\hline & \multicolumn{3}{|l|}{ Salinity } \\
\hline & Low & Moderate & High \\
\hline \multicolumn{4}{|l|}{$\mathrm{TX} \times \mathrm{CB}$ strain } \\
\hline Cultivation period (months) & 33 & 33 & 17 \\
\hline Months to harvest size $(76 \mathrm{~mm})$ & NA & 33 & NA \\
\hline Final shell height $(\mathrm{mm} \pm \mathrm{SE})$ & $68 \pm 3$ & $76 \pm 5$ & $59 \pm 3$ \\
\hline Maximum observed growth rate $\left(\mathrm{mm}\right.$ month $\left.^{-1}\right)$ & 8.3 & 21.1 & 21.7 \\
\hline Mortality (cumulative \%) & 57 & 100 & 100 \\
\hline WP (\%) & 0.7 & 4.3 & $1.6^{*}$ \\
\hline Correlation coefficient for WP vs. mortality & $\begin{array}{l}-0.24 \\
(P=0.25)\end{array}$ & $\begin{array}{l}0.25 \\
(P=0.24)\end{array}$ & $\begin{array}{l}0.83 \\
(P=0.00)\end{array}$ \\
\hline \multicolumn{4}{|l|}{$\mathrm{SC} \times \mathrm{CB}$ strain } \\
\hline Cultivation period (months) & 33 & 33 & 17 \\
\hline Months to harvest size $(76 \mathrm{~mm})$ & 32 & NA & NA \\
\hline Final shell height $(\mathrm{mm} \pm \mathrm{SE})$ & $79 \pm 2$ & $72 \pm 4$ & $56 \pm 3$ \\
\hline Maximum observed growth rate $\left(\mathrm{mm}\right.$ month $\left.^{-1}\right)$ & 12.8 & 17.1 & 13.8 \\
\hline Mortality (cumulative \%) & 33 & 100 & 100 \\
\hline WP (\%) & 0.3 & $3.4^{*}$ & $2.2^{*}$ \\
\hline Correlation coefficient for WP vs. mortality & $\begin{array}{l}0.00 \\
(P=0.19)\end{array}$ & $\begin{array}{l}0.54 \\
(P=0.01)\end{array}$ & $\begin{array}{l}0.60 \\
(P=0.03)\end{array}$ \\
\hline \multicolumn{4}{|l|}{$\mathrm{NC} \times \mathrm{CB}$ strain } \\
\hline Cultivation period (months) & 33 & 30 & 17 \\
\hline Months to harvest size $(76 \mathrm{~mm})$ & NA & NA & NA \\
\hline Final shell height $(\mathrm{mm} \pm \mathrm{SE})$ & $59 \pm 2$ & $73 \pm 3$ & $60 \pm 5$ \\
\hline Maximum observed growth rate $\left(\mathrm{mm} \mathrm{month}^{-1}\right)$ & 10.4 & 18.5 & 13.2 \\
\hline Mortality (cumulative \%) & 25 & 100 & 100 \\
\hline WP $(\%)$ & $0.6^{*}$ & 2.6 & $3.0^{*}$ \\
\hline Correlation coefficient for WP vs. mortality & $\begin{array}{l}0.49 \\
(P=0.01)\end{array}$ & $\begin{array}{l}0.28 \\
(P=0.20)\end{array}$ & $\begin{array}{l}0.66 \\
(P=0.01)\end{array}$ \\
\hline \multicolumn{4}{|l|}{$\mathrm{LA} \times \mathrm{CB}$ strain } \\
\hline Cultivation period (months) & 33 & 33 & 17 \\
\hline Months to harvest size $(76 \mathrm{~mm})$ & 27 & 26 & NA \\
\hline Final shell height $(\mathrm{mm} \pm \mathrm{SE})$ & $84 \pm 4$ & $84 \pm 6$ & $51 \pm 2$ \\
\hline Maximum observed growth rate $\left(\mathrm{mm}\right.$ month $^{-1}$ ) & 12.7 & 17.1 & 19.5 \\
\hline Mortality (cumulative \%) & 30 & 100 & 100 \\
\hline WP (\%) & 2.1 & 2.4 & $3.2^{*}$ \\
\hline Correlation coefficient for WP vs. mortality & $\begin{array}{l}0.20 \\
(P=0.34)\end{array}$ & $\begin{array}{l}0.38 \\
(P=0.08)\end{array}$ & $\begin{array}{l}0.58 \\
(P=0.04)\end{array}$ \\
\hline \multicolumn{4}{|l|}{ CB strain } \\
\hline Cultivation period (months) & 30 & 30 & 16 \\
\hline Months to harvest size $(76 \mathrm{~mm})$ & NA & NA & NA \\
\hline Final shell height $(\mathrm{mm} \pm \mathrm{SE})$ & $67 \pm 3$ & $68 \pm 3$ & $59 \pm 2$ \\
\hline Maximum observed growth rate $\left(\mathrm{mm} \mathrm{month}^{-1}\right)$ & 12.8 & 9.2 & 10.4 \\
\hline Mortality (cumulative \%) & 38 & 100 & 100 \\
\hline WP $(\%)$ & 0.6 & $1.9^{*}$ & $1.8^{*}$ \\
\hline Correlation coefficient for WP vs. mortality & $\begin{array}{l}0.06 \\
(P=0.77)\end{array}$ & $\begin{array}{l}0.59 \\
(P=0.00)\end{array}$ & $\begin{array}{l}0.79 \\
(P=0.00)\end{array}$ \\
\hline \multicolumn{4}{|l|}{$3 \mathrm{~N}$ strain } \\
\hline Cultivation period (months) & 22 & 29 & 38 \\
\hline Months to harvest size $(76 \mathrm{~mm})$ & NA & 35 & 18 \\
\hline Final shell height $(\mathrm{mm} \pm \mathrm{SE})$ & $55 \pm 3$ & $96 \pm 3$ & $80 \pm 5$ \\
\hline Maximum observed growth rate $\left(\mathrm{mm}\right.$ month $\left.^{-1}\right)$ & 12.4 & 13.8 & 19.9 \\
\hline Mortality (cumulative \%) & 29 & 100 & 72 \\
\hline WP $(\%)$ & 2.0 & 3.5 & 2.9 \\
\hline Correlation coefficient for WP vs. mortality & $\begin{array}{l}-0.35 \\
(P=0.19)\end{array}$ & $\begin{array}{l}0.17 \\
(P=0.47)\end{array}$ & $\begin{array}{l}-0.23 \\
(P=0.35)\end{array}$ \\
\hline
\end{tabular}


Table 2 Continued

\begin{tabular}{|c|c|c|c|}
\hline & \multicolumn{3}{|l|}{ Salinity } \\
\hline & Low & Moderate & High \\
\hline \multicolumn{4}{|l|}{ LA strain } \\
\hline Cultivation period (months) & 5 & 6 & 19 \\
\hline Months to harvest size $(76 \mathrm{~mm})$ & NA & NA & NA \\
\hline Final shell height $(\mathrm{mm} \pm \mathrm{SE})$ & $10 \pm 0.6$ & $9 \pm 0.5$ & $67 \pm 5$ \\
\hline Maximum observed growth rate $\left(\mathrm{mm}\right.$ month $\left.^{-1}\right)$ & 1.8 & 0 & 14.1 \\
\hline Mortality (cumulative \%) & 100 & 100 & 39 \\
\hline WP $(\%)$ & 0.2 & 1.2 & 0.0 \\
\hline Correlation coefficient for WP vs. mortality & $\begin{array}{l}0.24 \\
(P=0.49)\end{array}$ & $\begin{array}{l}-0.42 \\
(P=0.42)\end{array}$ & $\begin{array}{l}\text { undef } \\
\text { (NA) }\end{array}$ \\
\hline \multicolumn{4}{|l|}{ NC strain } \\
\hline Cultivation period (months) & 55 & 57 & 59 \\
\hline Months to harvest size $(76 \mathrm{~mm})$ & 23 & 25 & 22 \\
\hline Final shell height $(\mathrm{mm} \pm \mathrm{SE})$ & $96 \pm 4$ & $95 \pm 5$ & $105 \pm 6$ \\
\hline Maximum observed growth rate $\left(\mathrm{mm}\right.$ month $\left.^{-1}\right)$ & 13.8 & 19.1 & 12.6 \\
\hline Mortality (cumulative \%) & 82 & 86 & 100 \\
\hline WP $(\%)$ & 2.5 & 2.2 & $2.2^{*}$ \\
\hline Correlation coefficient for WP vs. mortality & $\begin{array}{l}-0.24 \\
(P=0.28)\end{array}$ & $\begin{array}{l}-0.10 \\
(P=0.66)\end{array}$ & $\begin{array}{l}0.49 \\
(P=0.02)\end{array}$ \\
\hline \multicolumn{4}{|l|}{$\mathrm{SC}$ strain } \\
\hline Cultivation period (months) & 48 & 50 & 48 \\
\hline Months to harvest size $(76 \mathrm{~mm})$ & 35 & 42 & 18 \\
\hline Final shell height $(\mathrm{mm} \pm \mathrm{SE})$ & $92 \pm 4$ & $83 \pm 2$ & $109 \pm 8$ \\
\hline Maximum observed growth rate $\left(\mathrm{mm} \mathrm{month}^{-1}\right)$ & 8.5 & 10.4 & 22.8 \\
\hline Mortality (cumulative \%) & 37 & 81 & 81 \\
\hline WP (\%) & 3.4 & 3.7 & 1.5 \\
\hline Correlation coefficient for WP vs. mortality & $\begin{array}{l}-0.02 \\
(P=0.93)\end{array}$ & $\begin{array}{l}0.04 \\
(P=0.89)\end{array}$ & $\begin{array}{l}0.619 \\
(P=0.07)\end{array}$ \\
\hline
\end{tabular}

*Significantly correlated with mortality.

TX, Texas; CB, Chesapeake Bay; SC, South Carolina; NC, North Carolina; LA, Louisiana; 3N, triploid, Louisiana.

growth was vigorous during the Fall of 1995, ceased during the Winter months, then resumed the following spring 1996 at which time oysters acquired $P$. marinus infections, ceased growing and died (Fig. 5). Conversely, strains NC and SC held at high salinity exhibited the more stepwise growth curves but did not experience severe mortality until the second or third Dermo disease challenge.

\section{Replication and transferability of data across study sites}

One site included in this study, Mobjack Bay, was used in two prior studies. Another site, Piankatank River, had low salinity similar to a previously studied site, Wye River. In both instances, observed annual variation in salinity and temperature for 1992-1993 (Brown et al. 1998), 1993-1994 (Brown et al. 2005) and 1995-2001 (this study) was remarkably similar in terms of the timing of annual highs and lows and with respect to minima and maxima. In addition, regardless of oyster strain, $\mathrm{WP}_{\max }$ was similar across the three studies, ranging from 1.4 to 3.3 at Mobjack Bay and, with one exception, ranging from 0.08 to 0.8 at the low salinity sites of Wye and Piankatank Rivers. Performance of the $\mathrm{CB}$ and NC strains also was remarkably consistent within strain across the studies. For example, the $\mathrm{CB}$ strain exhibited similar maximum growth rates $\left(12.8-14.9 \mathrm{~mm} \mathrm{month}^{-1}\right.$ at low salinity, and 7.7-15.0 $\mathrm{mm}$ month $^{-1}$ at Mobjack Bay), never attained market size at any site during any study, experienced severe mortality (60-100\%) subsequent to the first Dermo disease challenge at Mobjack Bay, and perished entirely following the second disease challenge. Conversely, the NC strain grew at consistent rates during all three studies (9.8-13.8 $\mathrm{mmmonth}^{-1}$ at low salinity and 11.7$19.1 \mathrm{~mm} \mathrm{month}^{-1}$ at Mobjack Bay), reached market size after 18-25 months of cultivation at Mobjack Bay, and survived more than 2 successive years of 
(a)

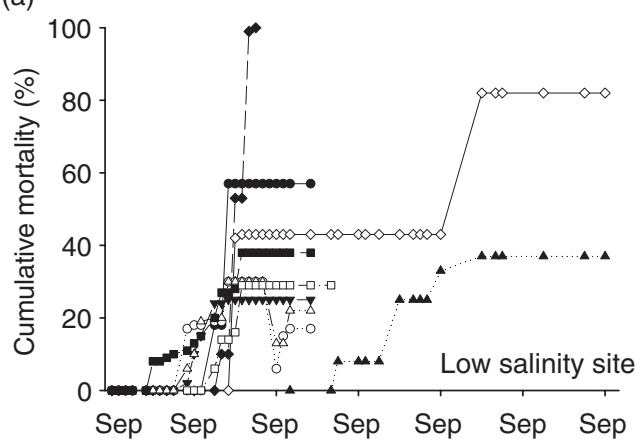

(b)
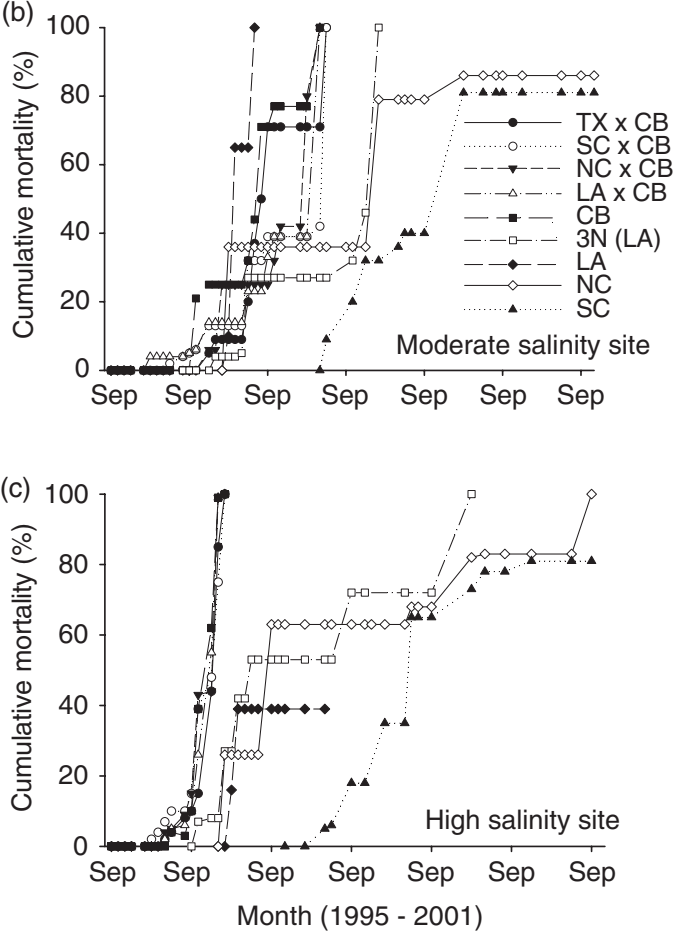

Figure 4 Mortality experienced by nine strains of oysters, Crassostrea virginica (Gmelin), cultivated in lower Chesapeake Bay during the period 1995-2001. (a-c) Illustrates the low, moderate and high salinity sites, respectively, as defined in Fig. 1.

Dermo challenge at that site (cumulative mortality $20-28 \%$ after the first challenge and $20-40 \%$ after the second challenge). The consistency in infection timing and intensity across three different studies along with the similar performance observed in three successive studies of $\mathrm{CB}$ and $\mathrm{NC}$ strains provides strong evidence that exposure and response to $P$. marinus does not differ greatly if oysters of the same strain are deployed at a particular site in different years.
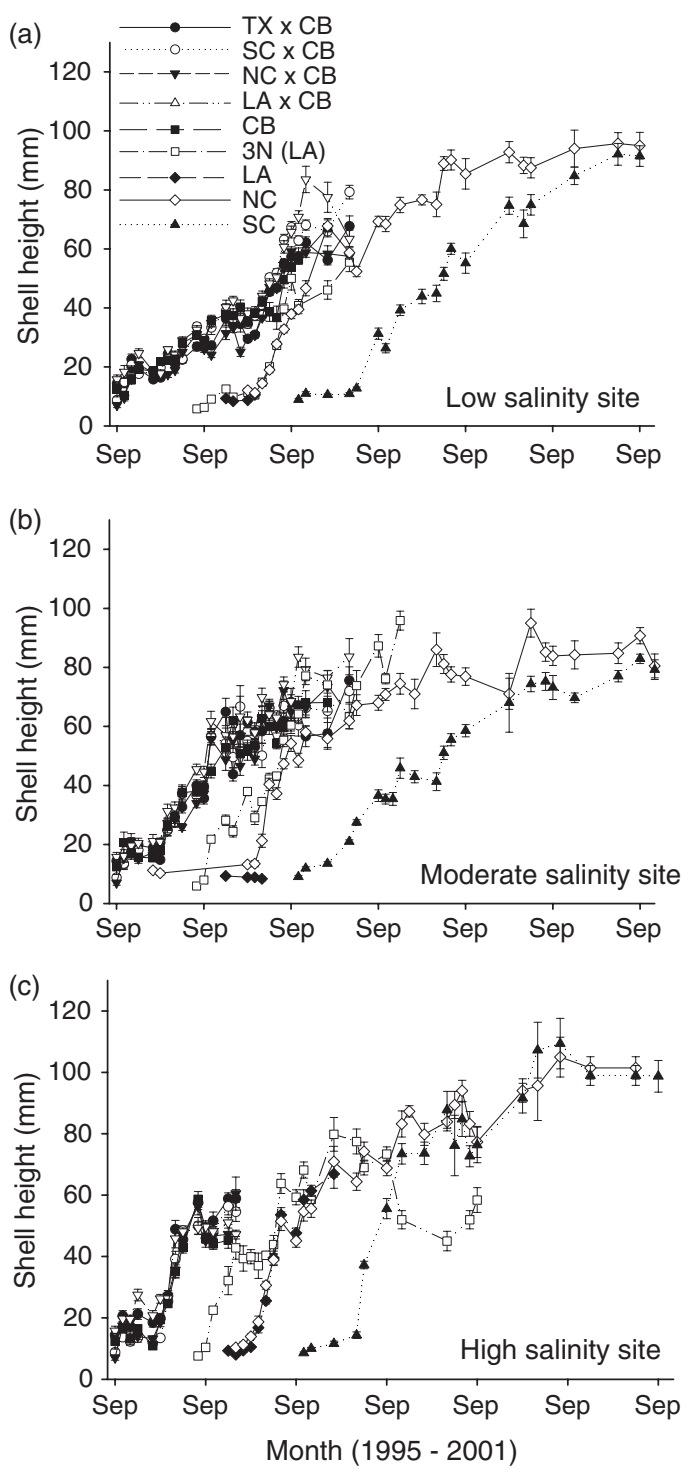

Figure 5 Growth measured as shell height for nine strains of oysters, Crassostrea virginica (Gmelin), cultivated in lower Chesapeake Bay during the period 1995-2001. $(\mathrm{a}-\mathrm{c})$ Illustrates the low, moderate and high salinity sites, respectively, as defined in Fig. 1.

\section{Discussion}

\section{Differences among sites}

The three sites evaluated in this study were typical of the range of habitats amenable to oyster culture in lower $\mathrm{CB}$ and despite the differences observed among sites, our results indicate that oyster cultivation at any of the sites would be technically and economically feasible provided appropriate strains and 
cultivation strategies are employed. Our results corresponded with the concept that temperature and salinity are the two most influential environmental stimulants of Perkinsus virulence in areas such as lower CB (Andrews 1988; Burreson \& Calvo 1996; Bushek and Allen 1996). For example, although the moderate salinity Mobjack Bay site had the highest intensity of Dermo $\left(\mathrm{WP}_{\max }=5.0\right.$ during the third summer), mortality at that site was significantly lower $(P<0.001)$ compared with the higher salinity site where $\mathrm{WP}_{\max }$ was lower, ranging from 1.3 to 3.2. This may have been because of virulence differences between parasite populations in high and moderate salinities, it may reflect the effects of hydrological differences such as flow rates and wave activity, or the oyster strains tested may tolerate Dermo better at moderate salinities than at high salinities. For instance, higher intensities may be more lethal in higher salinities, the resulting mortality effectively reducing the number of oysters with intense infection. For the Mobjack Bay site in particular, the consistency of $\mathrm{WP}_{\max }$ across this and two prior studies spanning the years 1992-2001, implies that Dermo parasite levels haves remained relatively constant at that location for some time despite annual hydrological variation. The fact that $\mathrm{CB}$ and $\mathrm{NC}$ strains exhibited significantly different levels of weighted prevalence and cumulative mortality, in addition to the fact that these differences between strains were repeated across years and under similar levels of Dermo disease pressure, implies differences in Dermo resistance among the two strains.

\section{Dermo resistance in $\mathrm{NC}$ and $\mathrm{SC}$ but not in $\mathrm{CB}$ oysters}

The functionality of Dermo resistance in oysters has to do with both accumulation (intake of exogenous parasites) and progression (proliferation of internal parasites) within oysters. Therefore, lack of severe mortality because of Dermo disease could be a manifestation of either low parasite abundance in the environment (reduced intake) or resistance (low proliferation or reduced effect of internal parasites), or a combination of the two factors. Variation in environmental parasite load is not likely a major factor in this study for three reasons. First, salinity (Fig. 2) and other hydrological characters monitored during this study showed similar temporal patterns that were paralleled by similar timing of the rise and fall in infection in those strains held simultaneously in any particular year (Fig. 3). Furthermore, intensity of infection peaked at similar times and at similar maxima for strains held concurrently during each year in the study (Fig. 3). Finally, two of the groups, $\mathrm{CB}$ and $\mathrm{NC}$, had previously been cultivated side-byside in the areas in two previous long-term studies and were observed to exhibit consistent patterns of growth, infection intensity and mortality (Brown et al. 1998, 2005). Challenged with up to six summers of Dermo disease exposure, the results with nonChesapeake strains parallel the results of Brown et al. (1998) and Brown et al. (2005), indicating that the NC, SC, and with a lesser degree of certainty the LA, strains demonstrate reduced levels of mortality when challenged by Dermo. In fact, at the sites where Dermo disease was notable (the moderate and high salinity sites), differences in survival observed between the non-Chesapeake oysters and oysters with Chesapeake heritage were remarkable. Figure $4 \mathrm{c}$ illustrates how dramatic the survival trends were, indicating that there is great promise for cultivating $\mathrm{NC}, \mathrm{SC}$ and possibly LA strains in higher salinity regions of $\mathrm{CB}$. Considering the levels of Dermo disease resistance and the fact that $\mathrm{NC}$ and $\mathrm{SC}$ also grew continually at the low salinity site also suggests that these non-Chesapeake strains could serve as ideal founders of selectively bred strains that will grow at all salinities for a sufficient length of time to reach harvest size.

\section{Hybrids between Chesapeake and other geographic strains of oysters}

The results for hybrids between Chesapeake and the other geographic strains contributes significantly to our knowledge of aquaculture performance of oyster strains because prior to this study, no information was available regarding the potential performance of hybrids between these non-Chesapeake strains and the remnant resident oysters. The $\mathrm{CB}$ strain, used in this study to generate the hybrid oysters, was derived from a native upper Bay stock and is considered to be representative of the majority of native oysters in the Bay interior (Brown \& Paynter 1991). Assuming a diverse oyster aquaculture industry were to employ alternative geographic strains such as NC, SC or LA, there would almost certainly occur some level of hybridization between the introduced strains and the native strain as oysters are broadcast spawners. The observation that all hybrid strains demonstrated excellent growth and survival at the low salinity site examined in this study indicates that such hybridization is likely 
to have no predictable negative effect on the native oysters in those areas. Conversely, the demise of the CB and its hybrid strains at the high salinity site implies that aquaculture performance in higher salinity areas has an important genetic component.

There are several implications of the observation that the hybrids between upper Bay oysters and all other geographic strains died following infection with Dermo at high salinity (one challenge) and moderate salinity (two challenges). First, there may be previously undetected differences between upper Bay oysters and those that occur in the high-salinity portions of lower CB. Because we used, at all test locations, a native oyster strain that was essentially the same as the James River oyster, we cannot discount that poor survival at the high salinity sites is not a stenohaline effect. If this is the case, precise examination of the potential effects of cultivating non-Chesapeake oyster strains in the high salinity regions of lower CB would require use of a lower Bay strain (e.g., Lynnhaven or Tangier). This would allow more accurate examination of the degree of resistance of hybrid progeny of Chesapeake vs. non-Chesapeake oysters in the higher salinity areas.

The survival curves suggest existence of a relationship between virulence of Dermo and resistance of infection by oysters similar to one that is commonly observed in plant agriculture. Host-pathogen co-evolution is a common observation in studies of wheat, maize and other agricultural crops (Simms 1996) and requires further investigation from a genetic standpoint in the oyster/Dermo system. Conversely, the complete mortality of $\mathrm{CB}$ and all of its hybrids held in both moderate and high salinity areas could be an indication that resistance to Dermo is a recessive character. Although recessive resistance is another common phenomenon observed in agricultural species (Nichols, Gabelman, Larson \&Walker 1965; MacKenzie \& Bishop 2001; Iyer \& McCouch 2004), a recessive gene for resistance to Dermo has not previously been observed in oysters and therefore, requires verification through creation and monitoring of additional hybrid families.

\section{Acknowledgments}

This research was funded in part by the Virginia Coastal Resources Management Program of the Virginia Department of Environmental Quality (DEQ) through Grant \# NA67OZ0360-01 of the National Oceanic and Atmospheric Administration (NOAA), Office of Ocean and Coastal Resource Management, under the Coastal Zone Management Act of 1972, as amended. The views expressed herein are those of the authors and do not necessarily reflect the views of NOAA or any of its subagencies or DEQ. Funding also was provided by Chesapeake Scientific Investigations Foundation. Special thanks are due to $\mathrm{M}$. Hooper who provided the NC broodstock, L. Burnett, N. Hadley and colleagues who provided several groups of SC oysters, J. Swartzenberg who provided the pure heritage NC strain, J. Supan who provided the LA triploids and R. G. Parks who provided the pure-heritage LA strain used in this study, K. Kester and R. Dyer who assisted with statistical analysis of results, and to X. Guo for comments on an earlier version of the manuscript. We thank J. Wesson, J. Register, A. Savage and N. Savage, and T. Hill and M. Hill for allowing us access to the waterfront and providing security during the study period. A. Teeling provided advice on various aspects of oyster culture, particularly tray construction.

\section{References}

Andrews J.D. (1988) Epizootiology of the disease caused by the oyster pathogen, Perkinsus marinus and its effects on the oyster industry. In: Disease Processes in Marine Bivalve Molluscs (ed. by W.S. Fisher), pp. 47-63. American Fisheries Society Special Publication No. 18, Bethesda, MD.

Brown B.L. \& Paynter K.T. (1991) Mitochondrial DNA analysis of native and selectively inbred Chesapeake Bay oysters (Crassostrea virginica). Marine Biolology 110, 343-352.

Brown B.L., Butt A.J. \& Paynter K.T. (1995) Comparative performance of cultured native and selectively bred eastern oysters, Crassostrea virginica, in floating rafts. Journal of Shellfish Research 14, 261 (abstract).

Brown B.L., Butt A.J., Shelton S.W. \& Paynter K.T. (1998) Growth and mortality of North Carolina-heritage oysters, Crassostrea virginica, in North Carolina and in Chesapeake Bay. Journal of Applied Aquaculture 8, 25-39.

Brown B.L., Butt A.J., Meritt D., Shelton S.W. \& Paynter K.T. (2005) Resistance of Dermo in eastern oysters, Crassostrea virginica (Gmellin), of North Carolina but not Chesapeake Bay Heritage. Aquaculture Research 36, 1391-1399.

Burreson E. \& Calvo L. (1996) Epizootiology of Perkinsus marinus disease of oysters in Chessapeake Bay, with emphasis on data since 1985. Journal of Shellfish Research 15, 17-34.

Bushek D. \& Allen S. Jr (1996) Races of Perkinsus marinus. Journal of Shellfish Research 15, 103-107.

Dame R. (1976) Energy flow in an intertidal oyster population. Estuarine and Coastal Marine Sciences 4, 243-253.

Iyer A.S. \& McCouch S.R. (2004) The rice bacterial blight resistance gene xa5 encodes a novel form of disease resistance. Molecular Plant-Microbe Interactions 17, 1348-1354. 
MacKenzie K. \& Bishop S.C. (2001) Resistance to infectious diseases in domestic livestock. Journal of Animal Science 79, 2057-2065.

Milbury C.A., Meritt D.W., Newell R.I. \& Gaffney P.M. (2004) Mitochondrial DNA markers allow monitoring of oyster stock enhancement in the Chesapeake Bay. Marine Biology 145, 351-359.

Nichols C.G., Gabelman W.H., Larson R.H. \& Walker J.C. (1965) The expression and inheritance of resistance to pink root in onion seedlings. Phytopathology 55, 752-756.

Paynter K.T. \& Burreson E.M. (1991) Effects of Perkinsus marinus infection in the Eastern oyster, Crassostrea virginica: II. Disease development and impact on growth at different salinities. Journal of Shellfish Research 10,425-431.

Paynter K.T. \& DiMichele L. (1990) Growth of tray cultured oysters (Crassostrea virginica Gmelin) in the Chesapeake Bay. Aquaculture 87, 289-298.

Paynter K.T., Pierce S. \& Burreson E.M. (1995) Levels of intracellular free amino acids used for salinity tolerance by oysters (Crassostrea virginica) are altered by protozoan (Perkinsus marinus) parasitism. Marine Biology 122 , $67-72$.
Ray S.M. (1952) A culture method for the diagnosis of infections with Dermocystidium marinum Mackin, Owen, and Collier in oysters. Science 116, 360-361.

Ray S.M. (1954) Biological Studies of Dermocystidium marinum, a Fungus Parasite of Oysters. Rice Institute Pamphlet, Houston, TX, 114pp.

Ray S.M. (1966) A review of the culture method for detecting Dermocystidium marinum, with suggested modifications and precautions. Proceedings of the National Shellfisheries Association 54, 55-69.

Simms E. (1996) The evolutionary genetics of plant-pathogen systems: understanding the coevolution of hosts and parasites is key to understanding their ecology. BioScience 46, 136-145.

Stokes N., Siddall M. \& Burreson E. (1995) Detection of Haplosporidium nelsoni (Haplosporidia: Haplosporidiidae) in oysters by PCR amplification. Diseases of Aquatic Organisms 23, 145-152.

United States Environmental Protection Agency (USEPA) (2000) Chesapeake Bay program: oyster restoration workshop proceedings and agreement statements. EPA 903-R00-005 and CBP/TRS 238-00. 